\title{
Radiološka obravnava ileokolične invaginacije pri otrocih
}

\section{Radiological Management of Ileocolic Intussusception in Children}

Domen Plut

\section{Izvleček}

Ileokolična invaginacija je uvlečenje končnega dela tankega črevesa v debelo črevo. Gre za pogost vzrok akutne trebušne bolečine in najpogostejši vzrok zapore črevesa pri otroku. Najpogosteje je idiopatska in se večinoma pojavi v prvih treh letih življenja. Predvsem pri starejših otrocih je vzrok invaginacije lahko tudi patološko vodilo. Glavni klinični znaki so krčevite bolečine v trebuhu, bruhanje in odvajanje krvave sluzi. Če invaginacija traja dalj časa, lahko pride do predrtja črevesa $z$ razvojem peritonitisa in septičnega šoka, kar lahko povzroči otrokovo smrt. Hitra prepoznava in obravnava tega stanja sta zato ključnega pomena. Klinična slika pri ileokolični invaginaciji pogosto žal ni značilna, zato ima pomembno vlogo radiološka obravnava, ki je odločilna tako pri diagnosticiranju kot pri zdravljenju. Diagnostična metoda izbire je ultrazvočna preiskava. Metoda izbire za neinvazivno razreševanje je hidrostatsko razreševanje $z$ ultrazvočnim nadzorom. Radiološko neinvazivno razreševanje je uspešno v približno $80 \%$ primerov. Če neinvazivno radiološko zdravljenje ni uspešno, je potreben nujen kirurški poseg. $\vee$ preglednem prispevku želimo temeljito predstaviti radiološko obravnavo ileokolične invaginacije pri otrocih.

Ključne besede: invaginacija, otrok, radiologija, ultrazvok, hidrostatska redukcija.

\begin{abstract}
Ileocolic intussusception is an invagination of the terminal ileum into the large bowel. It is a common cause of acute abdominal pain and the most common cause of ileus in children. Most intussusceptions are idiopathic and occur within the first three years of life. In older children, they can more often appear due to a pathological lead point. The typical clinical signs of intussusception are colicky abdominal pain, vomiting and bloody stools. If the intussusception is prolonged, perforation can occur, leading to diffuse peritonitis and septic shock. Further progression of the disease can be fatal. Therefore, quick recognition and treatment of the intussusception are crucial. Unfortunately, the clinical signs are often not typical, hence, radiology plays an important role. In diagnostics, ultrasound examination of the abdomen is the method of choice. For treatment, ultrasound-guided hydrostatic reduction is the method of choice for non-invasive treatment. Non-invasive radiological treatment is successful in around $80 \%$ of cases. When non-invasive treatment cannot resolve the condition, urgent surgery is required. The aim of this review article is to present in detail the radiological management of ileocolic intussusception in children.
\end{abstract}

Key words: child, intussusception, radiology, ultrasonography, hydrostatic reduction. 


\section{Uvod}

Ileokolična invaginacija je patoanatomsko stanje, pri katerem se končni del tankega črevesa (terminalni ileum) uvleče skozi ileocekalno zaklopko v debelo črevo (kolon). Uvlečeni del tankega črevesa imenujemo invaginat, sprejemni del debelega črevesa pa invaginiranec (1). Ileokolična invaginacija je pri otrocih pogost vzrok akutne trebušne bolečine, ki se najpogosteje (v več kot $80 \%$ ) pojavi pri otrocih med 6. in 36. mesecem starosti s pojavnostjo približno 1 primer na 1000 otrok v prvih treh letih življenja. Pogostejša je pri dečkih (63-67 \%) $(2,3)$. Ileokolična invaginacija je tudi najpogostejši vzrok črevesne zapore (ileusa) $v$ tej starostni skupini otrok (4).

Glede na vzrok nastanka invaginacije opredelimo kot idiopatske ali kot sekundarne. Pri idiopatskih invaginacijah za nastanek ni posebnega vzroka; vodilo so povečane mezenterične bezgavke in zadebeljeno limfatično tkivo v steni končnega dela tankega črevesa (Peyerjevi poloji), tako imenovano fiziološko vodilo. Te invaginacije so najpogostejše pri otrocih do tretjega leta starosti (5). Sekundarne invaginacije nastanejo zaradi patološkega vodila. Najpogostejše vodilo je Mecklov divertikel, sledijo podvojitvene ciste, polipi, limfom in drugo (6). Te invaginacije so pogostejše pri starejših otrocih (5).

\section{Patofiziologija invaginacije in klinična slika}

Pri invaginaciji zaradi uvlečenja črevesa pride do zapore, $v$ uvlečenem delu črevesa $z$ mezenterijem pa do stisnjenja mezenteričnega žilja. Stisnjenje povzroči venski in limfni zastoj, pojavita se edem črevesne stene in močnejše stisnjenje žilja, ki vodi tudi v motnje arterijskega pretoka. Sledita hipoksija in ishemija črevesne stene. Če stanje invaginacije traja, se pojavijo nekroza črevesne stene, predrtje in peritonitis (1). Temu patofiziološkemu dogajanju ustrezno sledijo tudi klinični znaki, ki so pri invaginaciji lahko značilni, včasih pa tudi ne. Prvi klinični znak je navadno nenadna, ponavljajoča se, krčevita in močna trebušna bolečina. Pridružen je jok, otrok priteguje spodnje ude $k$ trebuhu. Ob vztrajanju invaginacije znaki napredujejo, pojavijo se bruhanje in driska, sprva kri na blatu, nato mešanica blata in krvi, končno le krvava sluz. Klasična trojica znakov so napadi krčevite bolečine, bruhanje in krvava sluz oz. blato, vsi pa so prisotni le v približno četrtini primerov (7, 8). Pri daljšem trajanju invaginacije se pojavijo še izsušenost, povišana telesna temperatura, levkocitoza, peritonealni znaki in motnje zavesti, lahko celo krči (1). Bolezen ob nadaljnjem napredovanju lahko vodi v smrt. Da gre za resno in hitro potekajočo bolezen, nazorno govori podatek iz leta 2018 objavljene raziskave, $v$ kateri so pri otrocih $z$ ileokolično invaginacijo $v$ Ugandi ugotovili 32-odstotno smrtnost (9). Napredek v medicini ob pravočasni prepoznavi bolezni in uporaba modernih metod zdravljenja sta omogočila, da je stopnja smrtnosti v razvitem svetu manj kot $0,1 \%(10,11)$.

Da bi preprečili neugodno napredovanje stanja pri ileokolični invaginaciji, sta torej ključni zgodnje diagnosticiranje in hitro zdravljenje. Ker se pogosto zgodi, da je klinična slika neznačilna, neznačilni pa so tudi izsledki laboratorijskih izvidov, ima ključno vlogo radiološka obravnava.

\section{Radiološko diagnosticiranje pri kliničnem sumu na invaginacijo pri otroku}

\section{Ultrazvok}

Metoda izbire za potrditev ali izključitev prisotnosti ileokolične invaginacije pri otroku je ultrazvočna preiskava (UZ). Občutljivost in specifičnost sta 92-100 \% (12-15). Pregled opravimo s konveksno in linearno sondo, opra- vimo pa tudi oceno $z$ doplersko preiskavo. Pri UZ se invaginacija značilno prikaže kot tvorba, ki ima v prečnem preseku videz obroča v obroču (znak tarče), v vzdolžnem preseku pa je podobna ledvici ali vilicam (znak psevdo-ledvice ali vilic) (16) (Slika 1). Ocenimo morebitne spremembe stene črevesnih vijug invaginacije, tj. edem, izgubo slojevitosti in spremembo prekrvljenosti. Pri kratkotrajnem stanju invaginacije je pretok prisoten, pri dolgotrajnejšem pa lahko oslabljen ali odsoten, kar napoveduje možnost nekroze. Prednost UZ je, da lahko poleg prisotnosti invaginacije ocenjujemo tudi morebitno fiziološko ali patološko vodilo. Poleg same invaginacije lahko $z$ UZ ocenimo tudi prisotnost ileusa tankega črevesa, prosto tekočino, prosti plin ali peritonitis (1).

\section{Rentgensko slikanje}

Rentgensko (RTG) slikanje trebuha pri otrocih opravimo redko, običajno le pri sumu na ileus ali predrtje votlega organa.

Za RTG slikanje pri otroku z invaginacijo je značilen znak polmeseca, ki se prikaže kot polkrožna tvorba v svetlini debelega črevesa, ali znak zabrisanega roba jeter, če invaginacija sega do jetrnega zavoja debelega črevesa. Druge spremembe pri RTG so povezane s posledično zaporo črevesa - razširjene proksimalne črevesne vijuge in odsotnost plina $v$ poteku debelega črevesa (1) (Slika 2). Opisane spremembe pri RTG slikanju pogosto niso prisotne. Občutljivost RTG slikanja za diagnosticiranje ileokolične invaginacije je približno $48 \%$, specifičnost pa le $21 \%$ (13). Zaradi nizke diagnostične vrednosti in uporabe ionizirajočega sevanja RTG slikanje trebuha pri diagnosticiranju ileokolične invaginacije nima pomembnejše vloge.

\section{Fluoroskopija}

Fluoroskopsko slikanje trebuha z rektalnim vnosom kontrastnega sredstva (KS) je bilo vrsto let zlati standard za 
diagnosticiranje ileokolične invaginacije. Pri tej preiskavi v danko uvedemo Foleyjev kateter, skozi katerega črevo napolnimo s KS. Invaginacija se značilno prikaže z znakom polmeseca ali znakom navite vzmeti, ki sta posledica $\mathrm{KS}$, ki obliva invaginirane vijuge tankega črevesa v svetlini debelega črevesa (17) (Slika 3). Prednost te preiskave je poleg visoke občutljivosti in visoke specifičnosti tudi možnost neposrednega nadaljevanja preiskave v poskus razrešitve invaginacije, a je $v$ zadnjih desetletjih predvsem zaradi ionizirajočega sevanja več ne uporabljamo pogosto (16).

\section{Računalniška tomografija (CT)}

CT je sicer odlična metoda za prikaz ileokolične invaginacije $s$ kar $100 \%$ občutljivostjo, a zaradi velikega odmerka ionizirajočega sevanja pri otrocih ni prva metoda izbire (18). V poštev pride predvsem $v$ nejasnih primerih, v katerih sprememb z UZ nismo mogli opredeliti, in ko je pred nadaljnjim zdravljenjem potrebna boljša opredelitev, npr. za opredelitev patološkega vodila (Slika 4). V teh primerih sicer pride $v$ poštev tudi magnetnoresonančno slikanje.

\section{Zdravljenje ileokolične invaginacije}

Po potrjeni diagnozi ileokolična invaginacija se odločimo glede načina njenega razreševanja. $V$ poštev prideta dva načina, in sicer radiološko neinvazivno razreševanje in kirurško razreševanje. Pri odločitvi je ključna skupna presoja kirurga in radiologa, ki sta ocenjevala otrokovo stanje. Izbira načina zdravljenja temelji na presoji anamnestičnih podatkov, izsledkov kliničnega pregleda in izsledkov UZ preiskave. Izsledki UZ preiskave, na katerih presojamo možnost uspešne neinvazivne razrešitve, so prisotnost in količina tekočine intraperitonealno, prisotnost ujete tekočine $v$ invaginirancu med vijugami invaginata, prisotnost povečanih bez-

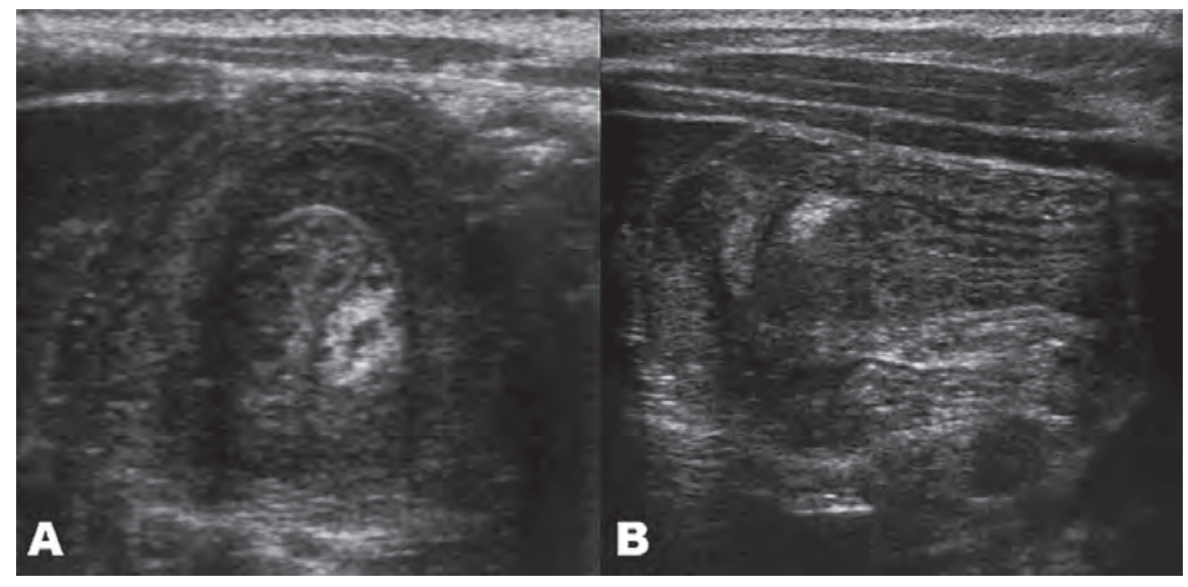

SLIKA 1. ZNAČILEN IZGLED ULTRAZVOČNI IZGLED ILEOKOLIČNE INVAGINACIJE PRI 14-MESEČNEM DEČKU. A - INVAGINACIJA $V$ PREČNEM PRESEKU Z VIDEZOM OBROČA $V$ OBROČU (ZNAK TARČE); B INVAGINACIJA V VZDOLŽNEM PRESEKU Z VIDEZOM LEDVICE (ZNAK PSEVDO LEDVICE).

FIGURE 1. TYPICAL ULTRASONOGRAPHIC APPEARANCE OF ILEOCOLIC INTUSSUSCEPTION IN A 14-MONTH- OLD BOY. IMAGE A SHOWS THE TRANSVERSE PLANE; THE INTUSSUSCEPTION APPEARS AS MULTIPLE RINGS OF DIFFERING ECHOGENICITY - A TARGET SIGN. IMAGE B SHOWS THE LONGITUDINAL VIEW; THE INTUSSUSCEPTION APPEARS AS A TUMOROUS MASS RESEMBLING A KIDNEY - A PSEUDO-KIDNEY SIGN.

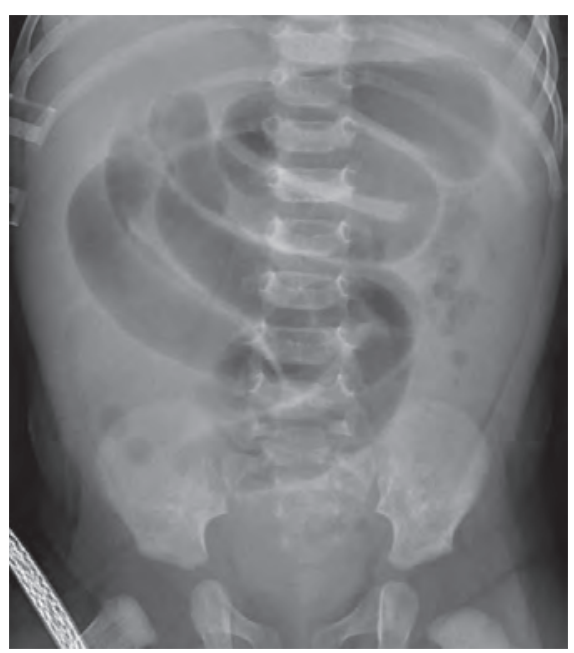

SLIKA 2. RENTGENOGRAM TREBUHA PRI 2-LETNEM DEČKU Z ILEOKOLIČNO INVAGINACIJO. VIDNA JE TUMORSKA TVORBA V DESNI POLOVICI TREBUHA Z ZNAKOM ZABRISANEGA ROBA JETER. IZRAŽENI SO TUDI ZNAKI ZAPORE TANKEGA ČREVESA (OBSTRUKCIJSKEGA ILEUSA).

FIGURE 2. ABDOMINAL X-RAY OF A 2-YEAROLD BOY WITH ILEOCOLIC INTUSSUSCEPTION. A TUMOROUS MASS CAN BE SEEN IN THE RIGHT HEMIABDOMEN OBSCURING THE NORMAL LIVER CONTOUR. DILATED SMALL BOWEL LOOPS AND THE ABSENCE OF GAS WITHIN THE COLON INDICATE INTESTINAL OBSTRUCTION. 


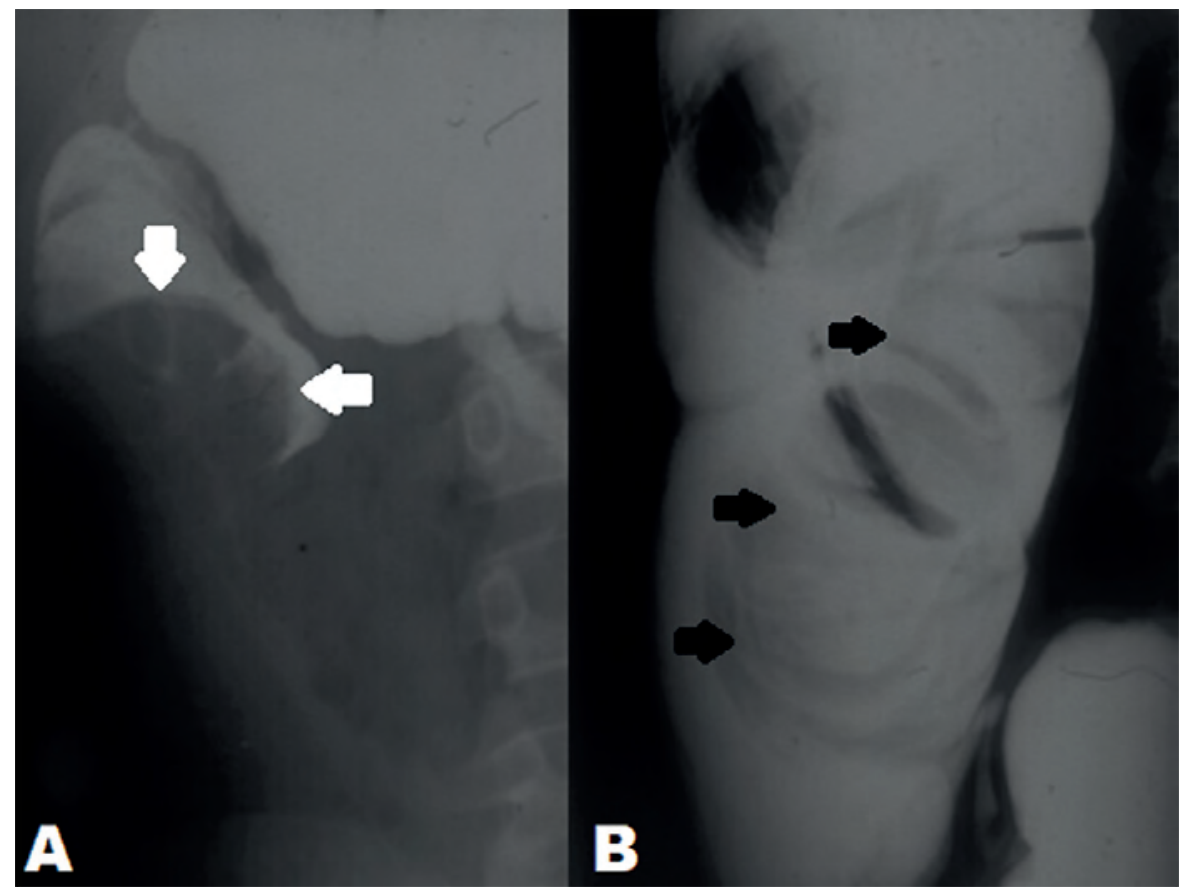

SLIKA 3. ZNAČILEN IZGLED ILEOKOLIČNE INVAGINACIJE PRI FLUOROSKOPSKEM SLIKANJU TREBUHA PO POLNJENJU ČREVESA S KONTRASTNIM SREDSTVOM PREKO DANKE. A - 13-MESEČNA DEKLICA S POLKROŽNO MOTNJO V POLNITVI V SVETLINI DEBELEGA ČREVESA, T. I. ZNAK POLMESECA (BELI PUŠČICI); B - 8-MESEČNI DEČEK Z VIJUGAMI TANKEGA ČREVESA V SVETLINI DEBELEGA ČREVESA, KI JIH OBLIVA KONTRASTNO SREDSTVO, T. I. ZNAK NAVITE VZMETI (ČRNE PUŠČICE).

FIGURE 3. TYPICAL APPEARANCE OF ILEOCOLIC INTUSSUSCEPTION AT BARIUM ENEMA FLUOROSCOPY. IMAGE A SHOWS A 13-MONTH-OLD GIRL, IMAGE B AN 8-MONTH-OLD BOY. THE INTUSSUSCEPTION CAN BE RECOGNISED BY THE CRESCENT SIGN (WHITE ARROW) IN IMAGE A AND BY THE COILED SPRING SIGN (BLACK ARROW) IN IMAGE B.

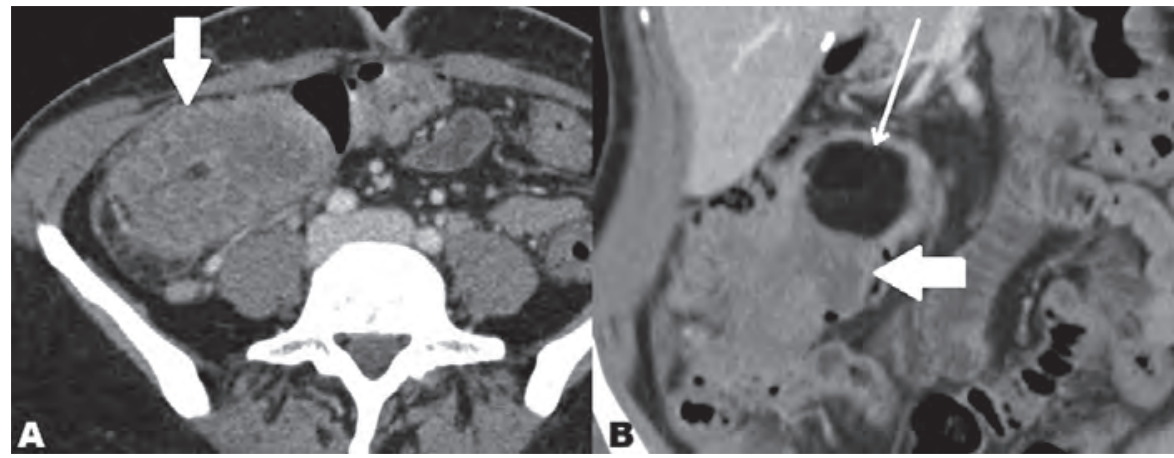

SLIKA 4. CT-POSNETEK ILEOKOLIČNE INVAGINACIJE PRI 17-LETNEM DEKLETU ZARADI NATANČNEJŠE OPREDELITVE PATOLOŠKEGA VODILA. ZNAČILEN IZGLED ILEOKOLIČNE INVAGINACIJE PRI CT V PREČNEM PRESEKU (A) IN V VZDOLŽNEM PRESEKU (B) (DEBELI BELI PUŠČICI); TANKA PUŠČICA - PATOLOŠKO VODILO, TJ. LIPOM.

FIGURE 4. ABDOMINAL COMPUTED TOMOGRAPHY (CT) IN A 17-YEAR-OLD GIRL WITH ILEOCOLIC INTUSSUSCEPTION. CT WAS PERFORMED TO CHARACTERISE THE PATHOLOGICAL LEAD POINT CAUSING THE INTUSSUSCEPTION. THE TYPICAL CT APPEARANCE OF INTUSSUSCEPTION IN THE TRANSVERSE PLANE (A) AND CORONAL PLANE (B) IS SHOWN (WIDE ARROW). THE PATHOLOGICAL LEAD POINT (THIN ARROW) TURNED OUT TO BE A LIPOMA gavk v invaginatu, prisotnost patološkega vodila in odsotnost krvnega pretoka v invaginatu. Če so prisotne navedene spremembe, je možnost uspešne neinvazivne razrešitve manjša (19). Odsotnost krvnega pretoka v steni invaginata je znak ishemije črevesne stene in jo obravnavamo kot relativno kontraindikacijo za poskus neinvazivnega razreševanja (1). Absolutna kontraindikacija za neinvazivno razreševanje so predrtje črevesa, peritonitis in šok. Tedaj je potreben kirurški poseg (16).

Če presodimo, da obstaja možnost uspešne neinvazivne razrešitve invaginacije, z njo poskusimo. $K$ posegu pristopimo takoj. Starše in tudi otroka, če je sposoben razumeti, seznanimo z namenom, vrsto in potekom posega. Pri posegu je prisoten tudi kirurg.

\section{Radiološke metode neinvazivnega razreševanja invaginacije}

Osnovno načelo neinvazivnega radiološkega razreševanja ileokolične invaginacije je uporaba povišanega tlaka, s katerim iztisnemo invaginat iz invaginiranca. Radiološke metode razreševanja se razlikujejo glede na način slikovne kontrole med postopkom in glede na sredstvo, ki ga uvedemo v debelo črevo za povišanje tlaka. Pri metodah, pri katerih uporabljamo slikovni nadzor z UZ, za dosego povišanega tlaka v širokem črevesu uporabljamo vodo, fiziološko raztopino ali zrak. Pri metodah, pri katerih uporabljamo slikovni nadzor s fluoroskopijo, pa za dosego povišanega tlaka uporabimo zrak ali kontrastno sredstvo (KS). Prednosti in pomanjkljivosti razpoložljivih metod navajamo v Tabeli 1.

V svetu danes najpogosteje uporabljamo hidrostatsko metodo z UZ nadzorom in pnevmatsko metodo s fluoroskopskim nadzorom, za kateri sta značilni visoka uspešnost razreševanja (več kot $80 \%$ ) in nizka verjetnost 
predrtja črevesa (približno $1 \%$ ) (16). V zadnjih letih se uveljavlja tudi pnevmatska metoda z UZ nadzorom, ki združuje prednosti uporabe plina za dosego višjega tlaka in nadzor z UZ v izogib ionizirajočemu sevanju. Za širšo uporabo te metode bi bile potrebne dodatne raziskave, predvsem glede vprašanja varnosti, saj s to metodo težko zaznamo morebitno predrtje črevesa (16). V Univerzitetnem kliničnem centru Ljubljana imamo bogate izkušnje z ultrazvočno preiskavo, ki je tudi dobro dostopna cel dan. Zato je pri nas metoda izbire hidrostatsko razreševanje z UZ slikovnim nadzorom, saj je ta način razreševanja zaradi odsotnosti ionizirajočega sevanja otroku najbolj prijazen.

\section{Opis postopka hidrostatskega} razreševanja z UZ slikovnim nadzorom

Za razreševanje uporabimo fiziološko raztopino, ki je ogreta na telesno temperaturo. To je zelo pomembno, da otroka med posegom ne podhladimo. Fiziološko raztopino natočimo v posodo (irigator), ki ima na dnu odprtino, na katero je nameščena cev za odtok. Na konec cevi namestimo rektalno cevko. Posodo s tekočino obesimo na stojalo za infuzije, ki mora biti vsaj en meter nad preiskovalno mizo, da dosežemo primeren hidrostatski tlak. Otroka obložimo z vpojnimi brisačami, da se v njih ujame tekočina, ki med posegom izteka ob rektalni cevki. Ko smo pripravljeni na poseg, kirurg rektalno cevko vstavi skozi zadnjik. Nato odpremo zaporo na cevki in skoznjo dovajamo tekočino v debelo črevo. Kirurg cevko med izvedbo ves čas drži čvrsto na mestu in hkrati stiska ritnici, s čimer pripomore k boljši tesnitvi in dosegu višjega tlaka znotraj črevesa. Radiolog medtem z UZ spremlja dovajanje tekočine $v$ debelo črevo in opazuje pomikanje invaginata (Slika 5). Debelo črevo običajno polnimo neprekinjeno štiri minute oz. manj, če nam pred tem že uspe razrešiti invaginacijo (1, 20). Znak uspešne razrešitve

\begin{tabular}{|c|c|c|}
\hline Metoda & Prednosti & Pomanjkljivosti \\
\hline $\begin{array}{l}\text { hidrostatska metoda } \\
\text { s fluoroskopskim } \\
\text { nadzorom }\end{array}$ & $\begin{array}{l}\text { - varna in zanesljiva } \\
\text { - dolgoletne izkušnje z uporabo } \\
\text { - enostavna in zanesljiva } \\
\text { - potrditev uspešne razrešitve }\end{array}$ & $\begin{array}{l}\text { - ionizirajoče sevanje } \\
\text { - večje tveganje zapletov v primeru } \\
\text { predrtja črevesa (zlasti ob uporabi } \\
\text { barijevega kontrastnega sredstva) } \\
\text { - omejena na prikaz } \\
\text { znotrajčrevesnega dogajanja -nižja } \\
\text { stopnja uspešne razrešitve }(67 \%)\end{array}$ \\
\hline $\begin{array}{l}\text { pnevmatska metoda } \\
\text { s fluoroskopskim } \\
\text { nadzorom }\end{array}$ & $\begin{array}{l}\text { - varna in zanesljiva metoda } \\
\text { - dolgoletne izkušnje z uporabo } \\
\text { - enostavna in zanesljiva potrditev } \\
\text { uspešne razrešitve -doseg } \\
\text { visokega tlaka znotraj črevesa } \\
\text { - majhna verjetnost zapletov ob } \\
\text { predrtju črevesa } \\
\text { - visoka stopnja uspešne razrešitve } \\
\text { (81\%) }\end{array}$ & $\begin{array}{l}\text { - ionizirajoče sevanje } \\
\text { - omejenost na prikaz } \\
\text { znotrajčrevesnega dogajanja } \\
\text { - draga fluoroskopska oprema }\end{array}$ \\
\hline $\begin{array}{l}\text { hidrostatska metoda z } \\
\text { ultrazvočnim nadzorom }\end{array}$ & $\begin{array}{l}\text { - varna in zanesljiva metoda } \\
\text { - dolgoletne izkušnje z uporabo } \\
\text { - visoka stopnja uspešne razrešitve } \\
\text { ( } 82 \% \text { ) } \\
\text { - odsotnost ionizirajočega sevanja } \\
\text { - majhna verjetnost predrtja črevesa } \\
\text { - izvedba na mestu obravnave } \\
\text { - zaznava patološkega vodila, } \\
\text { - cenovno ugodna }\end{array}$ & $\begin{array}{l}\text { - nižji končni tlak znotraj črevesa } \\
\text { - večja nevarnost zapletov v primeru } \\
\text { predrtja črevesa } \\
\text { - umazana izvedba preiskave }\end{array}$ \\
\hline $\begin{array}{l}\text { pnevmatska metoda z } \\
\text { ultrazvočnim nadzorom }\end{array}$ & $\begin{array}{l}\text { - visoka stopnja uspešne razrešitve } \\
\text { (93\%) } \\
\text { - odsotnost ionizirajočega sevanja } \\
\text { - doseganje visokega tlaka znotraj } \\
\text { črevesa } \\
\text { - izvedba na mestu obravnave } \\
\text { - cenovno ugodna }\end{array}$ & $\begin{array}{l}\text { - nezadostno preverjena metoda } \\
\text { - težja potrditev uspešne razrešitve } \\
\text { - težja prepoznava morebitnega } \\
\text { zapleta (predrtja črevesa) }\end{array}$ \\
\hline
\end{tabular}

TABELA 1. PREDNOST IN SLABOSTI RADIOLOŠKIH METOD NE-INVAZIVNEGA RAZREŠEVANJA ILEOKOLIČNE INVAGINACIJE.

TABLE 1. ADVANTAGES AND DISADVANTAGES OF RADIOLOGICAL METHODS FOR REDUCTION OF ILEOCOLIC INTUSSUSCEPTION. 


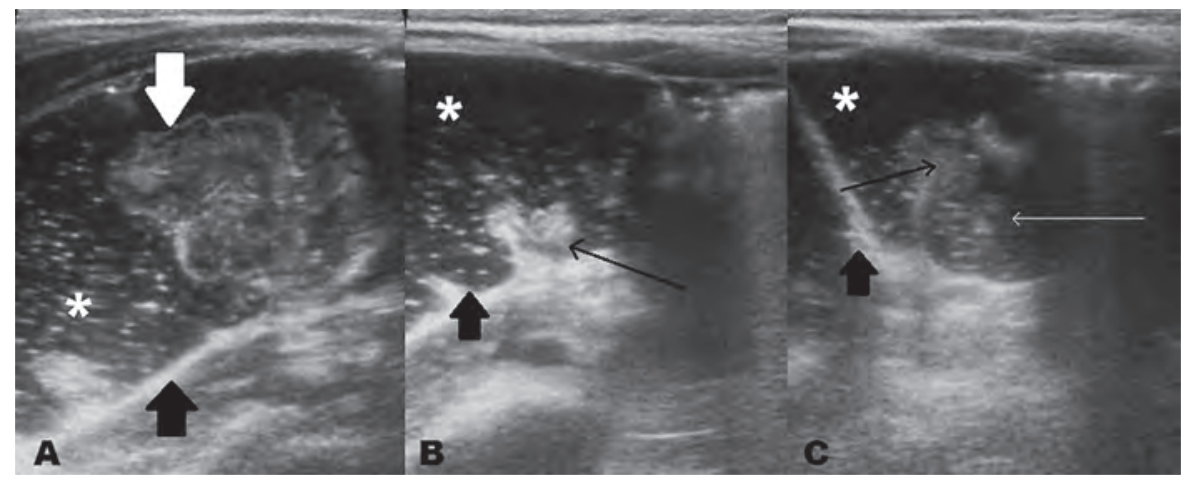

SLIKA 5. POSTOPEK RAZREŠEVANJA ILEOKOLIČNE INVAGINACIJE S HIDROSTATSKO METODO S FIZIOLOŠKO RAZTOPINO POD UZ NADZOROM PRI 14-MESEČNEM DEČKU. A - DEBELO ČREVO (DEBELA ČRNA PUŠČICA), KI GA MED POSTOPKOM RAZREŠEVANJA IZPOLNJUJEMO S FIZIOLOŠKO RAZTOPINO (*): V SVETLINI DEBELEGA ČREVESA SO VIJUGE TANKEGA ČREVESA (DEBELA BELA PUŠČICA), TJ. ZNAK INVAGINACIJE. B - DEBELO ČREVO, V CELOTI IZPOLNJENO S FIZIOLOŠKO TEKOČINO. VIDNA JE ILEOCEKALNA ZAKLOPKA (TANKA ČRNA PUŠČICA), VIJUG TANKEGA ČREVESA PA V SVETLINI DEBELEGA ČREVESA NI VEČ. C - ODPRTA ILEOCEKALNA ZAKLOPKA IN FIZIOLOŠKA RAZTOPINA V SVETLINI TANKEGA ČREVESA (TANKA BELA PUŠČICA) KOT ZANESLJIV ZNAK USPEŠNE RAZREŠITVE INVAGINACIJE.

FIGURE 5. ULTRASOUND-GUIDED HYDROSTATIC REDUCTION IN A 14-MONTH-OLD BOY. IMAGE A SHOWS THE ILEOCOLIC INTUSSUSCEPTION: SMALL BOWEL LOOPS (WIDE WHITE ARROW) WITHIN THE LARGE BOWEL (WIDE BLACK ARROW). THE LARGE BOWEL IS BEING FILLED WITH SALINE (*) DURING THE PROCEDURE. IMAGE B SHOWS THAT THE LARGE BOWEL IS COMPLETELY FILLED WITH SALINE, NO SMALL BOWEL LOOPS CAN BE SEEN WITHIN THE LARGE BOWEL ANYMORE. THE ILEOCAECAL VALVE CAN BE SEEN IN THE IMAGE (THIN BLACK ARROW). IMAGE C SHOWS REFLUX OF SALINE INTO THE SMALL BOWEL LOOPS (THIN WHITE ARROW) THROUGH THE OPEN ILEOCAECAL VALVE - A SIGN OF A SUCCESSFUL REDUCTION.

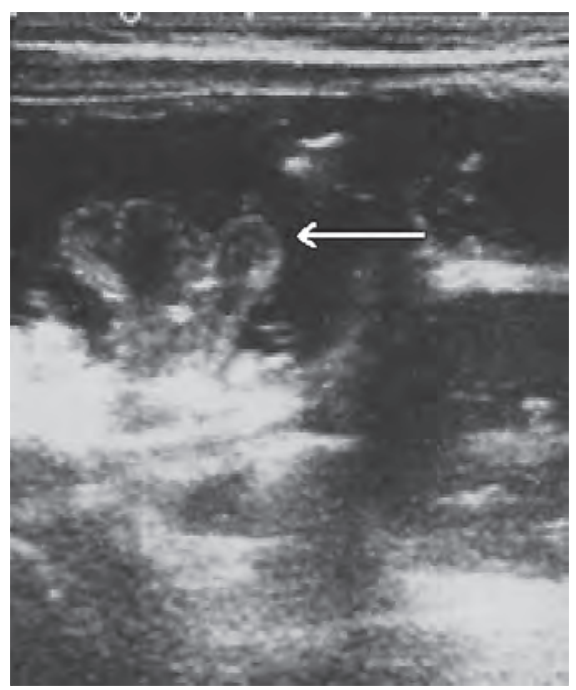

SLIKA 6. OBILNA ILEOCEKALNA ZAKLOPKA PO USPEŠNI RAZREŠITVI ILEOKOLIČNE INVAGINACIJE PRI 9-MESEČNI DEKLICI. ULTRAZVOČNA SLIKA PRIKAZUJE OBILNO OTEČENO ILEOCEKALNO ZAKLOPKO (PUŠČICA) PO USPEŠNI RAZREŠITVI DALJ ČASA TRAJAJOČE INVAGINACIJE. VIDEZ OBILNE ZAKLOPKE JE LAHKO PODOBEN VIDEZU OSTANKA INVAGINACIJE OB NEPOPOLNI RAZREŠITVI.

FIGURE 6. A LARGE ILEOCAECAL VALVE AFTER A SUCCESSFUL ULTRASOUND-GUIDED HYDROSTATIC REDUCTION PROCEDURE IN A 9-MONTH-OLD GIRL WITH A PROLONGED INTUSSUSCEPTION. THE LARGE OEDEMATOUS VALVE (ARROW) CAN RESEMBLE A RESIDUAL INTUSSUSCEPTION. je, ko opazimo, da invaginata v debelem črevesu ni več, tekočina pa skozi ileocekalno zaklopko vstopi v terminalni ileum.

Če razreševanje ni uspešno, a se invaginacija med posegom vsaj delno razreši, postopek čez 30 minut po možnosti ponovimo, če to dopušča otrokovo klinično stanje. Dokazano je namreč, da je lahko ponovni poskus razreševanja invaginacije ob predhodno delni razrešitvi uspešen pri dodatnih $50 \%$ invaginacij (6). Postopek je smotrno ponoviti trikrat (6). Tudi ob le delni dokončni razrešitvi se splošno stanje otroka običajno izboljša, kirurg pa pri operaciji, ki sledi, invaginacijo lažje dokončno razreši.

Zaradi invaginacije, predvsem, če traja dlje, se pojavi edem tudi v področju ileocekalne zaklopke. Včasih je lahko edematozna ileocekalna zaklopka po razrešitvi tako obilna, da pri UZ daje vtis ostanka invaginacije (Slika 6). V takšnih primerih težko presodimo, ali je razrešitev popolna, saj se lahko zgodi, da ob edemu tekočina ne prehaja v terminalni ileum (21). $V$ takšnem primeru se običajno odločimo za UZ sledenje.

Če med postopkom razreševanja pride do predrtja črevesa, je to na UZ vidno kot izlitje tekočine iz črevesa v trebušno votlino. Pri pnevmatskih metodah se predrtje črevesa kaže s prisotnostjo plina v trebušni votlini pri fluoroskopiji. To se pri neinvazivnem razreševanju zgodi izjemno redko, le pri približno $1 \%$ poskusov (16). Otroka v tem primeru kirurg nemudoma operira.

Pri nas za razreševanje invaginacije ne uporabljamo sedacije ali splošne anestezije. Njuna uporaba se med centri razlikuje. Nekateri avtorji pojasnjujejo, da je uporaba sedacije za razreševanje invaginacije koristna zato, ker sprosti krč gladkih mišic v črevesni steni (22), medtem ko drugi avtorji navajajo, da je razreševanje ob uporabi sedacije manj uspešno. To pojasnjujejo z odsotnostjo napenjanja pri otroku (manever po Valsalvi), ki preko enako- 
mernega povišanja znotrajtrebušnega tlaka zvišuje tlak znotraj črevesa in znižuje gradient tlaka na črevesno steno ter tako deluje tudi zaščitno pri predrtju črevesa (23). Prav tako si nasprotujejo tudi rezultati raziskav o uspešnosti razrešitve ob uporabi splošne anestezije $(24,25)$.

Po uspešni razrešitvi se $v$ približno $6-16 \%$ invaginacija ponovi (26-28). Pogostost ponovitve invaginacije ni odvisna od metode, ki jo uporabimo za razreševanje (26). Približno polovica ponovitev nastopi v prvih 48 urah po razrešitvi (29), zato stanje po razreševanju sledimo z UZ preiskavo, običajno pred odpustom otroka iz bolnišnice ali nemudoma ob nastopu ponovnih trebušnih bolečin. Če se invaginacija ponovi, postopek razreševanja opravimo še enkrat. Postopek je smotrno ponoviti trikrat, ob morebitnem vnovičnem pojavu invaginacije pa sledi kirurško zdravljenje (30). Razloga, zakaj se pri nekaterih otrocih invaginacija ponovi, ne poznamo. Nekateri avtorji navajajo, da so ponovitve invaginacij pogostejše pri invaginacijah s patološkim vodilom, v drugih raziskavah pa tega ne potrjujejo (16). Na splošno velja, da se patološka vodila pojavljajo pri približno 5-6 \% invaginacij, pri otrocih, starejših od 3 let, pa pri več kot $30 \%(6,31,32)$. Zato moramo biti pri otrocih $z$ invaginacijo, ki so starejši od treh let, izjemno pozorni na morebitno prisotnost patološkega vodila. Pri invaginacijah s patološkim vodilom je postopanje odvisno od tega, kdaj opazimo vodilo, tj. pri diagnosticiranju invaginacije ali med postopkom hidrostatske redukcije. $\checkmark$ prvem primeru, zlasti če je vodilo veliko, poizkus razrešitve ni indiciran in otroka kirurg operira, v drugem primeru, ko med razrešitvijo opazimo manjše vodilo, pa lahko postopek razrešitve nadaljujemo. Če razrešitev uspe, kirurg poskrbi za naknadno odstranitev vodila - kirurško ali z endoskopskim posegom (npr. polip) (1). Kirurško zdravljenje seveda sledi tudi neuspeli neinvazivni razrešitvi.
Pri približno 3-8 \% primerov invaginacij moramo s kirurškim posegom del odmrlega črevesa ali patološko vodilo odstraniti $(24,33,34)$. Tako ne moremo pričakovati, da bo neinvazivno zdravljenje tudi ob morebitnih nadaljnjih izboljšavah tehnike $v$ vseh primerih uspešno. Prav tako nam pove, da se predrtju črevesa kot redkemu zapletu zaradi odmrlega črevesa ne bomo mogli povsem izogniti. Tudi če se predrtje črevesa zgodi, to ne spremeni nadaljnjega ukrepanja, saj bi otrok z nerazrešeno invaginacijo $v$ vsakem primeru potreboval kirurško zdravljenje.

\section{Zaključek}

lleokoličina invaginacija je nujno stanje, ki je pri otrocih eden najpogostejših vzrokov akutne bolečine $v$ trebuhu in zapore črevesa. Neprepoznana lahko privede do težkega kliničnega stanja. Hitra prepoznava, diagnoza in zdravljenje so zato ključnega pomena. Radiološka obravnava je pomembna tako v diagnosticiranju kot zdravljenju invaginacije. Diagnostična metoda izbire je UZ metoda, metoda izbire za neinvazivno razreševanje pa hidrostatska z UZ slikovnim nadzorom. Če se invaginacija pojavi pri otroku, starejšem od treh let, moramo biti pozorni na morebitno prisotnost patološkega vodila.

\section{Literatura}

1. Mali S, Zupančič Ž, Maučec J, Plut D. Vloga radiologije pri diagnozi in terapije invaginacije pri otroku. Zbornik predavanj XLVI podiplomskega tečaja kirurgije za zdravnike. Ljubljana: Slovensko zdravniško društvo 2016: 32-9.

2. Lee EH, Yang HR. Nationwide population-based epidemiologic study on childhood intussusception in South Korea: emphasis on treatment and outcomes. Pediatr Gastroenterol Hepatol Nutr 2020; 23(4): 329-45.

3. Buettcher M, Baer G, Bonhoeffer J, Schaad $U B$, Heininger $U$. Three-year surveillance of intussusception in children in Switzerland. Pediatrics 2007; 120(3): 473-80

4. Hryhorczuk A, Lee EY, Eisenberg RL. Bowel obstructions in older children. AJR Am J Roentgenol 2013; 201(1): W1-8.
5. Applegate KE. Intussusception in children: evidence-based diagnosis and treatment. Pediatr Radiol 2009; 39 Suppl 2: S140-3.

6. Navarro OM, Daneman A, Chae A. Intussusception: the use of delayed, repeated reduction attempts and the management of intussusceptions due to pathologic lead points in pediatric patients. AJR Am J Roentgenol 2004; 182: 1169-76.

7. Harrington L, Connolly B, Hu X, Wesson DE, Babyn P, Schuh S. Ultrasonographic and clinical predictors of intussusception. J Pediatr 1998; 132: 836-9.

8. Lai AH, Phua KB, Teo EL, Jacobsen AS. Intussusception: a three-year review. Ann Acad Med Singapore 2002; 31: 81-5.

9. Akello VV, Cheung M, Kurigamba G, Semakula D, Healy JM, Grabski D, et al. Pediatric intussusception in Uganda: differences in management and outcomes with high-income countries. J Pediatr Surg 2020; 55: 530-4.

10. Parashar UD, Holman RC, Cummings KC, Staggs NW, Curns AT, Zimmerman CM, et al. Trends in intussusception-associated hospitalizations and deaths among US infants. Pediatrics 2000; 106: 1413-21.

11. Trotta F, Da Cas R, Bella A, Santuccio C, Salmaso $S$. Intussusception hospitalizations incidence in the pediatric population in Italy: a nationwide cross-sectional study. Ital J Pediatr 2016; 42(1): 89. 12. Hryhorczuk AL, Strouse PJ. Validation of US as a first-line diagnostic test for assessment of pediatric ileocolic intussusception. Pediatr Radiol 2009; 39:1075-9.

13. Carroll AG, Kavanagh RG, Ni Leidhin C, Cullinan NM, Lavelle LP, Malone DE. Comparative Effectiveness of Imaging Modalities for the Diagnosis and Treatment of Intussusception: A Critically Appraised Topic. Acad Radiol 2017; 24: 521-9.

14. Lehnert T, Sorge I, Till H, Rolle U. Intussusception in children--clinical presentation, diagnosis and management. Int J Colorectal Dis 2009; 24: 1187-92.

15. Samad L, Marven S, El Bashir H, Sutcliffe AG, Cameron JC, Lynn R, et al. Prospective surveillance study of the management of intussusception in UK and Irish infants. Br J Surg 2012; 99: 411-5 16. Plut D, Phillips GS, Johnston PR, Lee EY. Practical Imaging Strategies for Intussusception in Children. AJR Am J Roentgenol 2020; 215(6): 1449-63.

17. del-Pozo G, Albillos JC, Tejedor D, Calero $R$, Rasero M, de-la-Calle U, et al. Intussusception in Children: Current Concepts in Diagnosis and Enema Reduction. RadioGraphics 1999; 19 : 299-319.

18. Puapong D, Lee SL, Radner G, Tsai PI, Katz DS, Abbas MA, et al. Computed tomography findings of unanticipated prolonged ileocolic intussusception in children. The Permanente journal 2008; 12:22-4

19. He N, Zhang S, Ye X, Zhu X, Zhao Z, Sui X. Risk factors associated with failed sonographically guided saline hydrostatic intussusception reduction in children. J Ultrasound Med 2014; 33:1669-75

20. Talabi AO, Famurewa OC, Bamigbola KT, Sowande OA, Afolabi BI et al. Sonographic gui- 
ded hydrostatic saline enema reduction of childhood intussusception: a prospective study. BMC Emergency Medicine 2018; 18(1): 46.

21. Kanai R, Tamaki A, Sanabe N, Yamazato M, Kishaba Y, Zamami M. A case of edematous ileocecal valve masquerading as intussusception. Choonpa Igaku 2018; 45: 617-20.

22. Ilivitzki A, Shtark LG, Arish K, Engel A. Deep sedation during pneumatic reduction of intussusception. Pediatr Radiol 2012; 42: 562-5.

23. Katz ME, Kolm P. Intussusception reduction 1991: an international survey of pediatric radiologists. Pediatr Radiol 1992; 22: 318-22.

24. Purenne E, Franchi-Abella S, Branchereau S, Baujard C, Benhamou D, Mazoit JX. General anesthesia for intussusception reduction by enema. Paediatr Anaesth 2012; 22: 1211-5.

25. Suzuki M, Hayakawa K, Nishimura K, Koide M, Tateishi S, Yamamoto E, et al. Intussusception: the role of general anesthesia during hydrostatic barium reduction. Radiat Med 1999; 17: 121-4.

26. Esmaeili-Dooki MR, Moslemi L, Hadipoor A, Osia S, Fatemi SA. Pediatric Intussusception in Northern Iran: Comparison of Recurrent With Non-Recurrent Cases. Iran J Pediatr 2016; 26: e3898

27. Flaum V, Schneider A, Gomes Ferreira C, Philippe P, Sebastia Sancho C, Lacreuse I, et al. Twenty years' experience for reduction of ileocolic intussusceptions by saline enema under sonography control. J Pediatr Surg 2016; 51: 179-82.

28. Guo WL, Hu ZC, Tan YL, Sheng M, Wang J. Risk factors for recurrent intussusception in children: a retrospective cohort study. BMJ Open 2017; 7: e018604

29. Daneman A, Alton DJ, Lobo E, Gravett J, Kim $\mathrm{P}$, Ein SH. Patterns of recurrence of intussusception in children: a 17-year review. Pediatr Radiol 1998; 28: 913-9.

30. Hsu WL, Lee HC, Yeung CY, Chan WT, Jiang $C B$, Sheu JC, et al. Recurrent Intussusception: when Should Surgical Intervention be performed? Pediatr Neonatol 2012; 53: 300-3.

31. Tander B, Baskin D, Candan M, Basak M, Bankoglu M. Ultrasound guided reduction of intussusception with saline and comparison with operative treatment. Ulus Travma Acil Cerrahi Derg 2007; 13: 288-93.

32. Shekherdimian S, Lee SL. Management of pediatric intussusception in general hospitals: diagnosis, treatment, and differences based on age. World J Pediatr 2011; 7: 70-3.

33. Tota-Maharaj R, Rampersad B, Indalsingh R. Barium enema reduction of intussusception in a developing country. West Indian Med J 2010; 59: 535-9.

34. Karadag CA, Abbasoglu L, Sever N, Kalyoncu MK, Yildiz A, Akin M, et al. Ultrasound-guided hydrostatic reduction of intussusception with saline: Safe and effective. J Pediatr Surg 2015; 50: $1563-5$ asist. dr. Domen Plut, dr. med., specialist radiolog

(kontaktna oseba/contact person)

Klinični inštitut za radiologijo,

Univerzitetni klinični center Ljubljana

Zaloška cesta 7, 1000 Ljubljana

Medicinska fakulteta, Univerza v Ljubljani

Vrazov trg 2, 1000 Ljubljana

e-naslov: plut.domen@gmail.com

prispelo / received: 2. 11. 2020

sprejeto / accepted: 11. 3. 2021

Plut D. Radiološka obravnava ileokolične invaginacije pri otrocih. Slov Pediatr 2021; 28(2): 86-93. https://doi.org/10.38031/ slovpediatr-2021-2-03. 